\title{
CHALLENGES FOR THE MECHANICAL ENGINEERING AND METALWORKING INDUSTRY IN LATVIA
}

\begin{abstract}
Lasma Licite' ${ }^{1}$, Dr.oec.; Andris Sebins ${ }^{2}$, Bc.oec.
Abstract. One of the leading industries in Latvia is the mechanical engineering and metalworking industry; it generates high value added and supplies other industries of the national economy with machinery, technological systems and components. The research aim is to examine challenges for the mechanical engineering and metalworking industry in Latvia. The research found that workforce availability considerably affected mechanical engineering and metalworking enterprises, which was determined by emigration trends and the availability of specialists with adequate education and qualifications, as well as the level of earnings. Average earnings in manufacturing in the country are below the average; besides, they are not competitive with the earnings in the European Union. Nevertheless, the mechanical engineering and metalworking industry is one of the priority export industries to be supported in Latvia, as it contributes most to the GDP. The export volume of mechanical engineering and metalworking products was larger than that of goods of other categories, yet re-exports comprised a considerable proportion in the total exports of Latvia. An examination of the financial attractiveness of the industry revealed that in 2016 the average profit margin among mechanical engineering and metalworking enterprises was $12 \%$; besides, their net total profit totalled EUR 18 mln., which indicated that the industry was economically strong and attractive to potential entrepreneurs.
\end{abstract}

Key words: mechanical engineering, metalworking, industry.

JEL code: O14, L61, 011.

\section{Introduction}

In any developed country, manufacturing employs a considerable portion of the workforce. Moreover, manufacturing largely determines the economic potential of the country, its political and economic independence and the standard of living of the population (Fomins A., 2005); it is an essential source of innovation as well (Santos K., Loures E. et al., 2017; Dilberoglu U. M., Gharehpapagh B. et al., 2017). According to the Association of Mechanical Engineering and Metalworking Industries of Latvia (MASOC), in 2016 compared with 2015 the turnover of the manufacturing sector rose by $66 \%$, which was fostered by market expansion and overcoming export problems. Besides, the historically highest output was achieved in 2016, which allowed increasing the proportion of manufacturing in total value added, yet the proportion still considerably lagged behind the projected targets set by the National Development Plan of Latvia for 2014-2020 - the contribution of manufacturing to GDP has to reach $20 \%$ in 2020 and $26 \%$ in 2030, while the exports of goods and services, as a percentage of GDP, have to increase to $70 \%$ and $78 \%$, respectively.

One of the leading manufacturing industries in Latvia is mechanical engineering and metalworking, which encompasses design and construction of machines, mechanical engineering activities, manufacture of basic metals, manufacture and development of fabricated metal products, manufacture of electronic equipment, motor vehicles, medical instruments, repair and installation of machinery and equipment and other activities. One can conclude that it is a very important manufacturing supply chain link that links suppliers (steel and non-ferrous metal industries) and customers (various other industries). Setting the mechanical engineering and metalworking industry one of the priority industries in Latvia is in line with the economic transformation directions defined by the Smart Specialisation Strategy of Latvia - promotion of industries with future growth potential (smart materials, technologies etc.). The need to carry out economic transformation is conditioned by the regional development process and the aim to support high-productivity industries (Ciemleja G., Lace N., 2016). 
However, an analysis of the development of metal-related industries in Latvia allows concluding that the industries have faced sharp change periods, which occurred owing to diverse factors (Kamols U., Ivanova S. et al., 2014). In the early 1990s, the food and wood processing industries developed fast, while for the mechanical engineering and metalworking industry it was a problematic period, as the economic system established by the Soviet Union stopped existing after the collapse of it because it was not viable under the global market conditions (Mechanical Engineering and..., [s.a.]). This period was followed by the economic crisis of 1998-1999 in Russia; however, fast growth began by the year 2000, and since then the value added generated by the mechanical engineering and metalworking industry has increased many times, which was fostered by the availability of European Union (EU) funding for the modernisation of equipment, skills and knowledge built up in the industry (Strautins P., 2017) and the active development of new export markets, as well as local demand (Priede J., Skapars R., 2012).

Even though the performance of the industry was significantly affected by the financial crisis of 2008-2009 and the fact that the company Liepajas Metalurgs stopped operating in 2013, the mechanical engineering and metalworking industry contributed to $17 \%$ of the total turnover of manufacturing and $21 \%$ of the total exports of goods in 2015, according to the MASOC data. Besides, the mechanical engineering and metalworking industry is a strategic industry, it generates high value added and it supplies all the other industries of the national economy with machinery, technological systems and components (Latvijas Masinbuves un..., 2007). It has to be noted that in Latvia the manufacture and processing of metals and the manufacture of machinery and equipment comprise a significant proportion in the manufacturing sector, even though the proportion is lower in Latvia than, on average, in Europe. In terms of value, its total value added is almost the same as that of the food industry and the wood processing industry - these industries account for approximately $70 \%$ of the manufacturing sector (Strautins P., 2017).

The research has put forward a hypothesis - the development and financial attractiveness of the mechanical engineering and metalworking industry, to a great extent, are determined by workforce availability and export opportunities. The research aim is to examine challenges for the mechanical engineering and metalworking industry. To achieve the aim, the following specific research tasks were set: 1) to describe challenges in the workforce context for the mechanical engineering and metalworking industry; 2) to examine export opportunities for the mechanical engineering and metalworking industry; 3 ) to analyse the financial performance of the mechanical engineering and metalworking industry.

A number of research methods were employed to achieve the aim and perform the tasks. The monographic and descriptive methods were used to theoretically discuss and interpret the research results based on scientific findings and theories on the mechanical engineering and metalworking industry; statistical analysis - descriptive statistics and time series analysis - were applied to analyse the performance of the mechanical engineering and metalworking industry. Central Statistical Bureau (CSB) and MASOC data on the mechanical engineering and metalworking industry for the period 2008-2016, the theoretical and analytical literature on trends and factors influencing the industry were used as information sources.

\section{Challenges with workforce in the mechanical engineering and metalworking industry}

Trends in the labour market considerably affect the operation of any enterprise. In 2015, mechanical engineering and metalworking enterprises employed 20752 individuals, which 
accounted for $2.35 \%$ of the total nationally. The average level of labour productivity at the enterprises was slightly higher than the average in the manufacturing sector (Strautins P., 2017). However, the enterprises were significantly affected by workforce availability and the remuneration level.

Considerable structural changes in the labour market have been observed since 2009, the lowest point of the economic recession, when, according to the CSB, 38208 residents emigrated from Latvia, and a year later - 39651 . In view of the fact that the total population in Latvia in October 2017 was equal to $1.9 \mathrm{mln}$., one can estimate that the number of emigrants as a percentage of the total population was $9.34 \%$; moreover, it has to be taken into consideration that mostly working-age residents emigrated. This, in its turn, influences workforce availability for mechanical engineering and metalworking enterprises and does not contribute to the overall performance of the enterprises in the single European and global markets.

Furthermore, one can find that there is a lack of specialists of adequate qualification. As stated in the Informative Report on Labour Market Medium and Long-term Trends (2016) by the Ministry of Economics, young individuals do not prefer enrolling on mechanics and metalworking study programmes; consequently, the number of graduates is insufficient for normal reproduction of the workforce. Besides, there is a high student dropout rate in the engineering programmes. Nevertheless, experienced specialists and engineering graduates are very demanded in the labour market not only in Latvia but also abroad where their remuneration is often much higher than, on average, in Latvia. It has to be mentioned that there is still a widespread perception that the mechanical engineering and metalworking industry is associated with heavy work at unattractive workplaces, even though nowadays most of the enterprises use equipment instead of labour. As stressed in the mentioned report, 11.0 thousand high-qualification specialists are required in the manufacturing sector by 2020 .

Workforce availability for mechanical engineering and metalworking enterprises is also affected by the level of earnings, for low-qualification employees (stackers, assemblers, equipment operators etc.) in particular. This might be explained by the fact that production costs have to be as low as possible in order to have a competitive price on a product; it also relates to the inability to pay higher wages and salaries at the existing sales volumes and mark-ups.

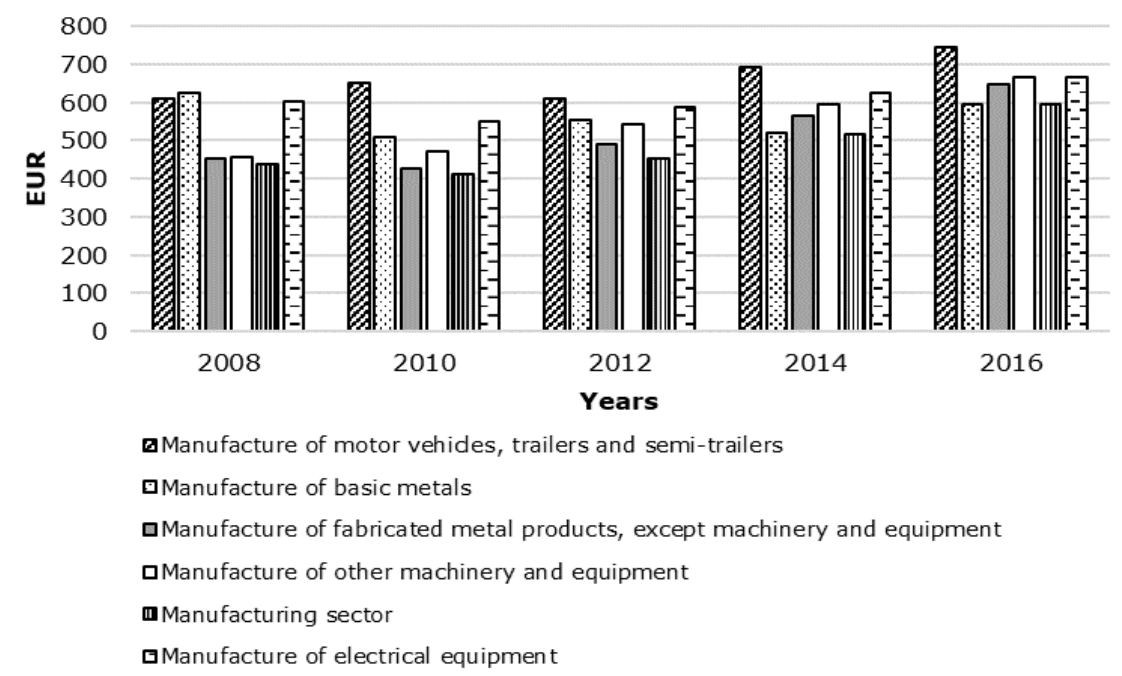

Source: authors' construction based on CSB data, 2017

Fig. 1. Average monthly employee earnings (net) in the manufacturing sector and in the sub-industries of mechanical engineering and metalworking in the period $2008-2016$, EUR 
An analysis of earnings in the mechanical engineering and metalworking industry reveals that changes in the earnings were the same as the overall earnings change trend, i.e. the earnings in this industry increased at the same rate as those in the entire economy (Fig. 1).

The average earnings level in the manufacturing sector was below the national average (in 2016, EUR 631 in the entire economy and EUR 593 in manufacturing), which could be explained both by the geographical location (the enterprises were mainly located outside the capital city, even though Riga contributed to more than half of the national GDP) and by the education level required by employers. In 2016, earnings were higher in the manufacture of fabricated metal products and other machinery and equipment than in the entire economy; besides, the earnings rose by more than $40 \%$ in the analysis period. Even though there are no accurate data, qualification requirements in the mechanical engineering and metalworking industry are higher than those in manufacturing, which is because of expensive equipment exploited in the industry. For this reason, employees of adequate qualification are necessary to reduce the risks, which, in its turn, determines higher earnings paid to them. Furthermore, there is a perception that the proportion of the shadow economy in the mechanical engineering and metalworking industry is lower, which could be affected by a number of factors. First, the enterprises belong to foreign investors, mainly from the EU Member States. Second, the enterprises are relatively large and a proportion of products exported by them is very high, sometimes even $100 \%$ are exported; for this reason, the enterprises have no easy access to cash and it is difficult for them to pay "under table money" even if they wished to do it (Strautins P., 2017).

It is important to analyse changes in value added in current prices with the aim to identify differences in change between various sub-industries and the entire economy. It has to be taken into consideration, of course, that the data are in current prices, that is why the real progress was not so considerable. However, there is no doubt that the manufacturers of electrical equipment and vehicle parts progressed more than the mechanical engineering and metalworking industry overall, exceeding the national average as well. During this period, a lot of foreign investors entered these industries and the scale of production increased (Strautins P., 2017).

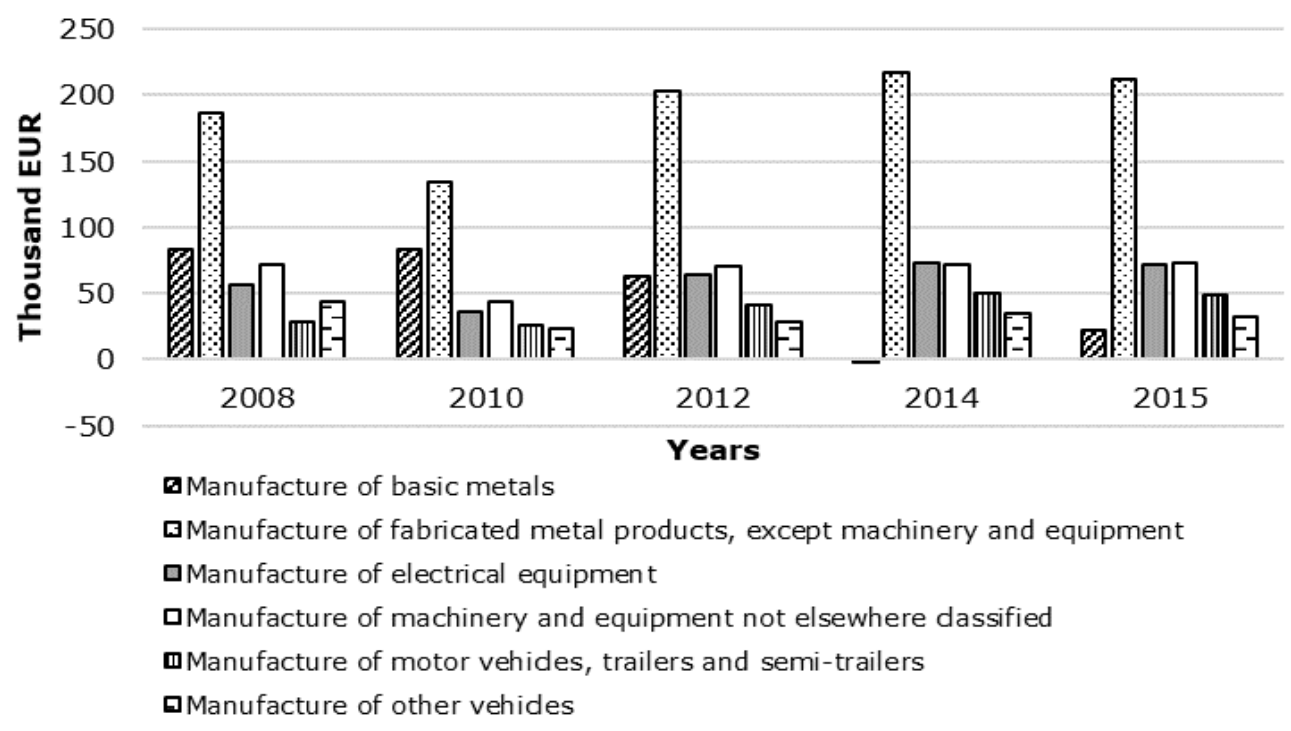

Source: authors' construction based on CSB data, 2017

Fig. 2. Value added in current prices in the sub-industries of mechanical engineering and metalworking in the period 2008 - 2015, thou. EUR 
As shown in Figure 2, in the period 2008-2015, the highest value added reported in the mechanical engineering and metalworking industry was generated in the manufacture of fabricated metal products as well as machinery and equipment not elsewhere classified, which might be explained by a larger output and a higher value of employees. However, the most significant valueadded increase was reported in the manufacture of motor vehicles, trailers and semi-trailers (by $75 \%$ in the analysis period) and electrical equipment (27\%), whereas in the entire economy a decrease in value added was observed $(-2.5 \%)$.

The earlier value chain stage a product is at, the greater the challenge to find ways how to generate higher value added for a product. Producing technologies and engineering systems for other industries, mechanical engineering and metalworking enterprises can adapt their products to global requirements in various ways, including through integrating innovative solutions in their products, taking into account the EU-defined fast-growing key-enabling technologies, offering solutions to energy efficient and waste-free production as well as finding solutions to automatized production, especially in labour-intensive industries. In addition, it is possible to develop technological solutions to new technologies of production of materials for the production and processing of smart materials as well as to develop new, specific industr--tailored innovative products or technologies (Masinbuves kompetences centra..., 2016). It has to be also noted that production in this industry involves manual work when performing such operations as lathing, welding and other unautomated operations done physically, which allows selling such products with a higher value, thus generating higher value added from labour. This requires stressing the advantages of product individuality and fast-made changes in the product, which is not easy to do in automated production. Besides, the mechanical engineering and metalworking industry has a relatively low degree of specialisation, which allows the enterprises to adapt their technologies to new requirements and to be flexible (Nacionalas industrialas politikas..., 2013).

\section{Trends in mechanical engineering and metalworking industry exports}

The mechanical engineering and metalworking industry, according to the intermediate report on the implementation of the "Guidelines on Promoting Exports of Latvian Goods and Services and Attracting Foreign Investments for 2013-2019" in the period 2013-2015 produced by the Ministry of Economics, is defined as one of the priority export industries to be supported, which could be explained by the fact that it is one of the industries most contributing to the GDP of Latvia and is mainly an export-oriented industry (exports account for up to $80 \%$ of the total output).

In 2016, according to the CSB, mechanical engineering and metalworking industry exports totalled EUR 1129949 (if the exports of electronics producers are included) or EU 802591 (if excluded). Nevertheless, it has to be stressed that this statistic is not accurate because products are exported by intermediaries whose key registered economic activity is not the production of goods (Strautins P., 2017). The key export markets for Latvia are nearby countries with a high standard of living and high purchasing power. Enterprises of Latvia are competitive in the Scandinavian markets owing to lower workforce costs; the manufacture of metal products is labour intensive, which often allows the enterprises to successfully market their similar-quality products that are available in the domestic market (of the exporting country), but at a lower price or with some extra added value. Norway, Germany, Sweden and Denmark consume $50 \%$ of mechanical engineering and metalworking industry exports from Latvia, being potential markets also for those enterprises that only begin exporting their products (Makroekonomisko norisu parskats, 2016). Such scientists as J. Priede and R. Skapars (2012) identified the quality competitiveness of the 
metal industry of Latvia in iron and steel product groups of trade between Latvia and main trade partners (Lithuania, Estonia, Germany and Russia). Calculations showed that the quality and value added of exports were higher than those of imports. That indicates the quality competitiveness of Latvia in its main export markets.

However, if analysing the proportion of goods produced by the examined industries in the total exports, one has to take into account the fact that a significant proportion of the exports of Latvia is represented by re-exports that are typical of the countries having large transit flows of goods and serving as distribution centres. Not all the goods transited through Latvia appear in export statistics, e.g. coal, which is not produced in Latvia. According to experts of the Bank of Latvia, the average proportion of re-exports in the total exports make up about $30 \%$. The proportion of mechanical engineering and metalworking industry re-exports is higher than the average for the entire economy. A much more accurate amount of exports might be shown by the total turnover of the examined industries, as the mechanical engineering and metalworking industry exports, except for metalworking, actually account for $90 \%$ and even more of the total exports (Strautins P., 2017). In the result, the analysis of CSB data on the proportion of exports in the total turnover of the examined industries reveals that this indicator for the mechanical engineering and metalworking industry is higher than the average for the entire economy, yet that for metalworking is slightly lower. The indicator for the manufacture of other vehicles is considerably lower. As regards metalworking, there is a large number of "garage type" or small enterprises whose labour productivity might be low and/or they do not report all their economic activities. The small-scale manufacture of metal structures is associated with "shadow" small-scale construction. In contrast, there is only one indicator for the activity - manufacture of other vehicles - that reflects the economic problems of the industry (Strautins P., 2017). Nevertheless, promoting exports is important, as it significantly affects labour productivity (Shatrevich Z., Zvanitajs J., 2011; Bernard A. B., Jensen J. B., 2004; Clerides S. K., Lach S. et al., 1998).

\section{Characteristics of the financial performance of the engineering and metalworking} industry

To identify the financial attractiveness of and challenges for the mechanical engineering and metalworking industry, it is important to analyse the financial performance of the industry. The data on after-tax profit margins indicate that there were two sub-industries that had very attractive profit/cost ratios: manufacture of fabricated metal products and manufacture of motor vehicles, trailers and semi-trailers. In both sub-industries, profit margins were $12.8 \%$ and $22.8 \%$, respectively, even though in the period 2010-2016 the sub-industries demonstrated a decrease in their profits by $29 \%$ and $51 \%$. Their financial performance was affected by the specifics of their products, investment amounts and overall market trends. The situation in the other sub-industries was either similar to that in the manufacturing sector and the entire economy or considerably worse (Table 1).

The present research analysed also profits made by mechanical engineering and metalworking enterprises. One can conclude that the enterprises made profits, except those engaged in the following activities: manufacture of other vehicles and manufacture of basic metals - because the company Liepajas Metalurgs exited the market. This fact considerably affected the performance of the sub-industry. 
Financial performance of the engineering and metalworking industry in the period 2010-2016

\begin{tabular}{|c|c|c|c|c|c|c|c|c|c|}
\hline & Indicators & 2010 & 2011 & 2012 & 2013 & 2014 & 2015 & 2016 & $\begin{array}{l}\text { Average } \\
\text { change }\end{array}$ \\
\hline \multirow{4}{*}{ 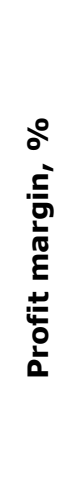 } & $\begin{array}{l}\text { Manufacture of } \\
\text { fabricated metal } \\
\text { products }\end{array}$ & -20.1 & 15.1 & 11.7 & 15.6 & 10.3 & 11.0 & 12.8 & -29.19 \\
\hline & $\begin{array}{l}\text { Manufacture of } \\
\text { machinery and } \\
\text { equipment not } \\
\text { elsewhere classified }\end{array}$ & 3.8 & 7.5 & 12.3 & 11.2 & -6.5 & 1.7 & -0.05 & -39.12 \\
\hline & $\begin{array}{l}\text { Manufacture of } \\
\text { electrical equipment }\end{array}$ & 12.3 & 16.7 & 34.8 & 23.9 & 15.4 & 16.5 & 8.5 & 5.99 \\
\hline & $\begin{array}{l}\text { Manufacture of } \\
\text { motor vehicles, } \\
\text { trailers and semi- } \\
\text { trailers }\end{array}$ & 11.1 & 17.3 & 16.0 & 18.5 & 23.9 & -27.6 & 22.8 & -50.82 \\
\hline \multirow{4}{*}{ 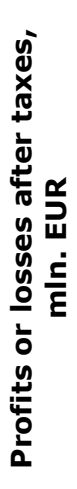 } & $\begin{array}{l}\text { Manufacture of } \\
\text { fabricated metal } \\
\text { products }\end{array}$ & -13.4 & 11.6 & 11.7 & 20.2 & 14.3 & 13.8 & - & -29.15 \\
\hline & $\begin{array}{l}\text { Manufacture of } \\
\text { machinery and } \\
\text { equipment not } \\
\text { elsewhere classified }\end{array}$ & 1.9 & 4 & 7.2 & 7.1 & -3.9 & 1.1 & - & -18.80 \\
\hline & $\begin{array}{l}\text { Manufacture of } \\
\text { electrical equipment }\end{array}$ & 4.8 & 6.5 & 15.5 & 14.1 & 11.2 & 13.7 & - & 33.32 \\
\hline & $\begin{array}{l}\text { Manufacture of } \\
\text { motor vehicles, } \\
\text { trailers and semi- } \\
\text { trailers }\end{array}$ & 5.1 & 8.5 & 9.0 & 11.2 & 12.8 & -16 & - & -22.74 \\
\hline
\end{tabular}

Source: authors' calculations based on CSB data

The overall trend in relation to financial performance, however, is downward sloping. The financial performance of enterprises is often affected by their financial burden with regard to loans, i.e. paying back interest and principal can considerably worsen the financial performance. It is particularly true for the enterprises that are not yet stable and develop fast - buy new equipment and increase their production capacity. This might be explained by the fact that the total amount of investment in tangible assets was larger in the mechanical engineering and metalworking industry than in the manufacture of basic metals, the design and construction of machines and the manufacture of electronics but smaller than in the chemical industry and the motor vehicle industry.

The analysis of the CSB data on financial obligations of mechanical engineering and metalworking enterprises in 2016 shows that the level of liabilities was moderate (the debt ratio on the balance sheet was 0.612 ; the short-term debt ratio was 0.405 ; the liabilities-to-equity ratio was 1.597), which could be explained by the stable profits of the enterprises and the fact that more than $50 \%$ of the enterprises in the industry were older than five years (Rutkovska A., 2015). This means that large and older/more stable enterprises have already gone through the start-up stage when a lot of borrowed capital is needed for their fast development - purchase of equipment as well as for current assets. However, loans are relatively easy to get and loan terms and conditions are favourable for the expansion of enterprises. Of course, average performance indicators of an industry usually "hide" large differences among individual enterprises. There are several enterprises in the mechanical engineering and metalworking industry that played a 
disproportionally large role in growth in the industry, and the funds needed for the enterprises were provided by their foreign owners.

Liquidity in the mechanical engineering and metalworking industry was quite high (according to the CSB, the overall liquidity ratio in the metalworking sub-industry was 1.266), which indicates an enterprise's efficiency of using its assets. An exception was the manufacture of vehicles with the overall liquidity ratio of 0.712 , which reveals that large and inefficient investments were made in the past and that the particular sub-industry is risky for activity and investment in it. Nevertheless, overall, the metalworking enterprises of Latvia are able to meet their short-term liabilities.

The average asset turnover ratio in the metalworking sub-industry was considerably higher than that in the entire economy, 1.596 and 0.903, respectively, in 2016. Overall, the asset turnover ratio gives insight into how stable the sub-industry is; the data are comprehensive and cover also the enterprises with a ratio of below 1 , while some enterprises have a ratio of above 5 . Relative to the averages of the entire economy, the metalworking sub-industry demonstrates strong positions.

\section{Conclusions, proposals, recommendations}

1) Mechanical engineering and metalworking enterprises are considerably affected by workforce availability. Latvia lacks specialists with adequate education and qualifications; engineers emigrate to other countries where earnings are competitive. Besides, there is a widespread perception that the mechanical engineering and metalworking industry is associated with heavy work at unattractive workplaces, which does not contribute to the interest of potential specialists in the mechanical engineering and metalworking industry.

2) The availability of the workforce for the mechanical engineering and metalworking industry is considerably affected by workforce remuneration. The average earnings level in the manufacturing sector was below the national average (in 2016, EUR 631 in the entire economy and EUR 593 in manufacturing), which could be explained both by the fact that the enterprises were mainly located outside the capital city.

3) In the period 2008-2015, the highest value added reported in the mechanical engineering and metalworking industry was generated in the manufacture of fabricated metal products as well as machinery and equipment not elsewhere classified, which might be explained by a larger output and a higher value of employees. The earlier value chain stage a product is at, the greater the challenge to find ways how to generate higher value added for a product.

4) The mechanical engineering and metalworking industry is one of the priority export industries to be supported, as it most contributes to the GDP of Latvia. The key export markets for Latvia are the Scandinavian countries due to their high standard of living and high purchasing power. Even though the export volume of mechanical engineering and metalworking products is larger than that of goods of other categories, re-exports comprise a considerable proportion in the total exports of Latvia.

5) In 2016, the average profit margin among mechanical engineering and metalworking enterprises was $12 \%$, which demonstrated the attractiveness of the industry for entrepreneurs and stimulated the establishment of new enterprises and provided profit-making opportunities for the existing ones. Besides, the enterprises made a net total profit of EUR $18 \mathrm{mln}$. in 2016, which indicated that the industry was economically strong and attractive to potential entrepreneurs. 


\section{Bibliography}

1. Association of Mechanical Engineering and Metalworking Industries of Latvia. Retrieved: www.masoc.Iv. Access: 31.01.2018.

2. Bernard, A.B., Jensen, J.B. (2004). Why Some Firms Export. Review of Economics and Statistics, Vol. 86, No. 2. pp. 561-569.

3. Central Statistical Bureau of Latvia. Retrieved: www.csb.gov.Iv/en. Access: 31.01.2018.

4. Ciemleja, G., Lace, N. (2016). Opportunities for Sustainable Development and Challenges in Nanotech Industry in Latvia. Journal of Security and Sustainability Issues, Volume 5, Issue 3, pp. 432-436.

5. Clerides, S.K., Lach, S., Tybout, J.R. (1998). Is Learning by Exporting Important? Micro-dynamic evidence from Colombia, Mexico, and Morocco. The Quarterly Journal of Economics, Volume 113, Issue 3, pp. 903947.

6. Dilberoglu, U.M., Gharehpapagh, B., Yaman, U., Dolen, M. (2017). The Role of Additive Manufacturing in the Era of Industry 4.0. Procedia Manufacturing, Volume 11, pp. 545-554.

7. Fomins, A. (2005). Latvijas rupniecibas attistibas tendences un perspektivas (Trends and Prospects of Latvian Industry). Riga: LU, p. 242.

8. Kamols, U., Ivanova, S., Kamola, L. (2014). Industrial Development Latvia and its Major Cities and Towns. In: XII International Scientific Conference "Management and Engineering '14": Conference Proceedings. Vol. 2, Bulgaria, Sozopol, 22.-25. June, 2014. Sozopol: TU Sofia, 2014, pp. 1026-1035.

9. Latvijas masinbuves un metalapstrades rupniecibas nozares apraksts (Description of the Mechanical Engineering and Metalworking Industry) (2007). Riga, p. 52.

10. Makroekonomisko norisu parskats 2016 (Macroeconomic Developments Report 2016) (2016). Latvijas Banka. No. 24, p. 96.

11. Masinbuves kompetences centra attistibas strategija (Strategy for the Development of the Mechanical Engineering Competence Centre). (2016). Riga, p. 84.

12. Mechanical Engineering and Metalworking Industry in Latvia (s.a.) Investment and Development Agency of Latvia. p. 84.

13. Nacionalas industrialas politikas pamatnostadnes 2014. - 2020. gadam (Guidelines for the National Industrial Policy for 2014-2020) (2013). Ministry of Economics. p. 40.

14. National Development Plan of Latvia for 2014 - 2020 (2012). p. 70.

15. Par Latvijas precu un pakalpojumu eksporta veicinasanas un arvalstu investiciju piesaistes pamatnostadnu 2013.-2019.gadam istenosanas 2013. - 2015.gada starpposma novertejumu (Intermediate Assessment of the Implementation of the Guidelines on Promoting Exports of Latvian Goods and Services and Attracting Foreign Investments for 2013-2019 in the Period 2013-2015) (2016). Ministry of Economics, Riga, p. 27.

16. Priede, J., Skapars, R. (2012). Quality Competitiveness of Latvia's Metal Industry in the Iron and Steel Product Groups. Economics and Management, Volume 17, Issue 1, pp. 202-208.

17. Rutkovska, A. (2015). Uznemumu demografija Latvija (Demography of Enterprises in Latvia). Retrieved: https://www.makroekonomika.Iv/uznemumu-demografija-latvija. Access: 31.01.2018.

18. Santos, K., Loures, E., Piechnicki, F., Canciglieri, O. (2017). Opportunities Assessment of Product Development Process in Industry 4.0. Procedia Manufacturing, Volume 11, pp. 1358-1365.

19. Shatrevich Z., Zvanitajs, J. (2011). Export and Manufacturing Productivity Growth Effect on Macroeconomic Situation in Latvia. In: Practice and Research in Private and Public Sector -11: 1st International Scientific Conference, Lietuva, Vilnius, 5-6 May, 2011. Vilnius: Mykolas Romeris University, 2011, pp. 308-315.

20.Strautins, p. (2017). Latvijas Konkuretspejas Zinojums 2016. Masinbuve un metalapstrade Latvija (Report on the Competitiveness of Latvia 2016. Mechanical Engineering and Metalworking in Latvia). Riga, p. 19. 